2. Pellman EJ, Viano D, Casson IR, et al. Concussion in professional football: injuries involving 7 or more days out: part 5 . Neurosurgery 2004;55:1100-1119.

3. Pellman EJ, Viano D, Casson IR, et al. Concussion in professional football: players returning to the same game: part 7 . Neurosurgery 2005;56:79-92.
4. Tsao JW, Perry BN, Kennedy CH, Beresford R. Predicting prolonged recovery after concussion. Neurology 2014;83: 2196-2197.

5. Browner WS. Discussion. In: Publishing and Presenting Clinical Research. Philadelphia: Lippincott Williams \& Wilkins; 2006.

\title{
CORRECTIONS
}

\section{vCJD in the United States - Analysis of 4 Cases (P2.329)}

In the 2015 AAN Annual Meeting abstract "vCJD in the United States - Analysis of 4 Cases (P2.329)" by D. Saenz et al. (Neurology ${ }^{\circledR}$ 2015;84:P2.329), there are two errors. The second sentence under 'Results' should read: “....all confirmed by tonsillar and/or brain tissue at autopsy." The second sentence under 'Conclusion' should read: “...2 of the 4 affected individuals visited the UK at some point during the incubation period.” The authors regret the errors.

\section{Induced Normothermia in Severe Traumatic Brain Injury Patients (P7.168)}

In the 2015 AAN Annual Meeting abstract "Induced Normothermia in Severe Traumatic Brain Injury Patients (P7.168)" by D. Green-LaRoche et al. (Neurology ${ }^{\circledR}$ 2015;84:P7.168), there are two errors. In the Methods, it should read that all patient data and resources for the project originated from a single institution, Boston Medical Center ("BMC"). The last sentence of the Acknowledgments should read "We thank Tudor Sturzoiu, Boston University School of Medicine, for providing the data extraction and analysis for this project." The authors regret the errors.

Safety and Effectiveness of Lacosamide as Adjunctive Treatment for Partial-onset Seizures (POS) in Hispanic/ Latino Patients from Mexico: Post-hoc Analysis of an Open-label Trial (P4.265) and Safety and Effectiveness of Lacosamide as a First Add-on (FAO) or Later Add-on (LAO) Treatment of Partial-onset Seizures (POS) in Adults: an Open-label Trial (P4.262)

In the 2015 AAN Annual Meeting abstracts "Safety and Effectiveness of Lacosamide as Adjunctive Treatment for Partialonset Seizures (POS) in Hispanic/Latino Patients from Mexico: Post-hoc Analysis of an Open-label Trial (P4.265)" by H. Ceja Moreno et al. (Neurology $\left.{ }^{\circledR} 2015 ; 84: P 4.265\right)$ and "Safety and Effectiveness of Lacosamide as a First Add-on (FAO) or Later Add-on (LAO) Treatment of Partial-onset Seizures (POS) in Adults: an Open-label Trial (P4.262)" by W.W. Zadeh et al. (Neurology ${ }^{\circledR}$ 2015;84:P4.262), there is an error in the byline. Plamen Tzvetanov does not meet the criteria for authorship and should not have been included in the author list. The AAN Scientific Programming staff regrets the error. 


\section{Neurology}

Safety and Effectiveness of Lacosamide as Adjunctive Treatment for Partial-onset

Seizures (POS) in Hispanic/Latino Patients from Mexico: Post-hoc Analysis of an Open-label Trial (P4.265) and Safety and Effectiveness of Lacosamide as a First Add-on (FAO) or Later Add-on (LAO) Treatment of Partial-onset Seizures (POS) in Adults: an Open-label Trial (P4.262)

Neurology 2015;85;111

DOI 10.1212/WNL.0000000000001822

This information is current as of July 6, 2015

Updated Information \& Services

Permissions \& Licensing

Reprints including high resolution figures, can be found at: http://n.neurology.org/content/85/1/111.3.full

Information about reproducing this article in parts (figures,tables) or in its entirety can be found online at:

http://www.neurology.org/about/about_the_journal\#permissions

Information about ordering reprints can be found online:

http://n.neurology.org/subscribers/advertise

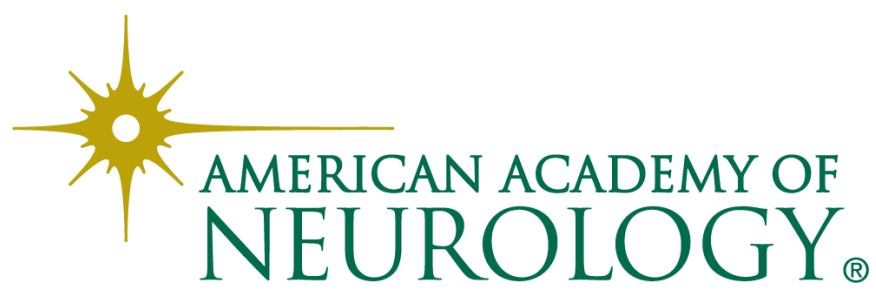

